\title{
DEVELOPMENT OF INTERACTIVE MULTIMEDIA USING LECTORA INSPIRE FOR VEHICLE BODY CONSTRUCTION COURSES IN UNIVERSITAS SRIWIJAYA
}

\author{
Imam Syofii ${ }^{1}$, Dewi Puspita Sari ${ }^{1 *}$ \\ ${ }^{1}$ Department of Mechanical Engineering Education, Universitas Sriwijaya, Indralaya-30662, South Sumatera, \\ Indonesia
}

\begin{abstract}
This study aims to developing interactive multimedia using Lectora inspire for vehicle body construction courses for Universitas Sriwijaya students. The Lectora inspire software was used because easy to operate and can be made interactive electronic learning. Research and development method were used because it is an effective for developing multimedia and able to test the effectiveness of the product. Based on results, the interactive multimedia using Lectora inspire software are valid with percentage of $87.5 \%$ for multimedia and $86.9 \%$ for matters, practice with percentage in small group test of $85.52 \%$ and field test of $86.61 \%$, and effective because based on post-test results $80 \%$ of respondents was passed. Thus, interactive multimedia using Lectora inspire software for vehicle body construction courses proper to use in Mechanical Engineering Education study program, Universitas Sriwijaya.
\end{abstract}

Keywords: Interactive Multimedia, Lectora inspire software, Research and Development Method.

\section{INTRODUCTION}

Learning process is an interaction process between tutors with student. A good learning process occurs if has a systematic learning program, where them has a strategy so that results of learning is good and measurable [1]. Utilization of technology is something that should be done so that learning strategies become effective [2]. In addition, utilization of technology for avoid the tutor becomes the dominant source of learning, where conditions were not effective and interactive. Thus, interactive multimedia is needed for learning to be effective and efficient.

Multimedia is a combination of types of media, where it is a combination of text, graphics, animation, sound and or images [3]. Multimedia is usually made interactive for learning to be interesting or called interactive multimedia [4]. Interactive multimedia can create curiosity about the content of matter [5]. Therefore, the interaction in the learning process between tutor or teacher with student becomes good [5].

Vehicle body construction is one of the course in Mechanical Engineering Education study program at Universitas Sriwijaya with basic competencies: the history of vehicle body development; vehicle body design (aerodynamics, ergonomic and aesthetic factor); vehicle body components; vehicle body repair method; and vehicle body welding method. These matters are appropriate when formed in interactive multimedia so that basic competencies are easy to understand. Interactive multimedia developed using Lectora inspire software is proposed.

The Lectora inspire software is software that often used for developing electronic-learning (elearning) because it can be made interactive. Since the Lectora inspire was widely used for online courses and presentations. In addition, the Lectora inspire has several advantages [6]: can used to create websites; the features that support the creation on interactive e-learning; the features provided are user friendly; has many template; and support by other application such as Sagit and Camtasia Flypaper. Therefore, interactive multimedia that is user friendly and interactive is needed so that the delivery of matters for vehicle body construction courses was better. Thus, this study examines the development of interactive

\footnotetext{
*Corresponding author’s email: dewipuspita@fkip.unsri.ac.id
} 
multimedia using the Lectora inspire software was proposed for the vehicle body construction courses for application in the in Mechanical Engineering Education study program at Universitas Sriwijaya.

\section{METHODOLOGY}

This study was used the research and development (R and D) method proposed by Sugiyono [7]. The $\mathrm{R}$ and $\mathrm{D}$ method is an effective for developing multime[7]. The multimedia development uses three stage of testing [8]: one to one (3 respondents); small group (10 respondents), and field test (one class or 40 respondents). The activity flow diagram can be seen in Figure 1.dia because this method able to test the effectiveness of the product

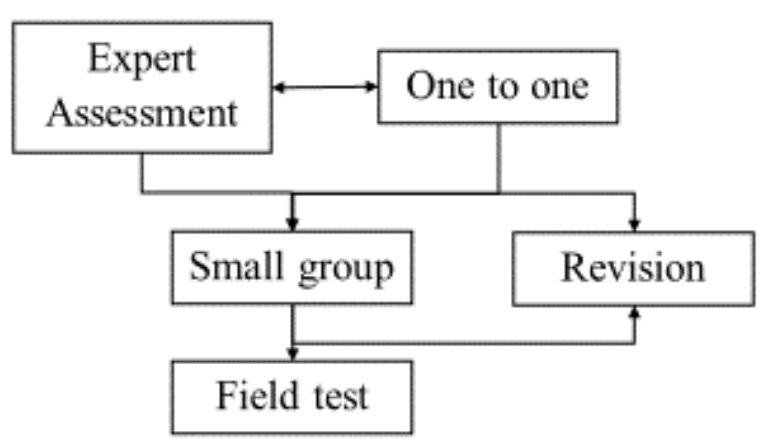

Figure 1 Flow of activities [1]

Expert assessment is an effort to find out the weaknesses of the media and matters developed by asking with experts [1]. In one to one stage, the response subject about interactive multimedia developed is done through interviews and questionnaires. After revision based on response of subject in one to one stage has been done the next is small group test. In this session, the prototype (interactive multimedia developed) testes on 10 people. Next, field test to know the validity, effectiveness, and practicality of prototype.

The validity, effectiveness, and practicality were carried out using quantitative methods, Equation 1 is an example of analysis,

$$
\begin{aligned}
& \text { Percentage }(\%)= \\
& \frac{\text { observation results }}{\text { maximum score }} \times 100 \%
\end{aligned}
$$

After that, the calculation results using Equation 1 are categorized using Table 1.

Table 1. Description value

\begin{tabular}{ll}
\hline Percentage & Interpret \\
\hline $76-100 \%$ & Valid \\
$56-75 \%$ & Enough \\
$40-55 \%$ & Less \\
$0-39 \%$ & Not \\
\hline
\end{tabular}

\section{RESULTS AND DISCUSSIONS}

The processed data in this AQA-web is retrieved from the internal data of the Mechanical Engineering Department, Sriwijaya University.

The data will be delivered in the form of master data, which has been grouped based on entities and attributes.

The entities and attributes or the data is written using alphanumeric or pdf. On the other hand, the external data are retrieved in the form of REST API, which is originally belong to the Information, Communication, and Technology Center of Sriwijaya University.

\subsection{Results and Discussions}

Based on the validity test, the percentage of feasibility of interactive multimedia using the Lectora inspire software was $87.5 \%$, categorized as valid. However, there suggestions to address namely improve font so that the matters are easy to read. After the prototype is repaired (prototype 2 ), the next step is the matters validation. Based on tested, percentage of matters validation was $86.9 \%$, categorized as valid too. Therefore, prototype 2 is worth testing one to one, small group, field test stage.

Based on one to one tested, the respondents ( 3 peoples) gave an assessment that prototype 2 was user friendly and quite interactive, where they without being guided are able to run the prototype smoothy. Based on small group tested, the average respondents (10 peoples) gave a rating of $85.52 \%$, categorized valid (very good). They (10 peoples) can run prototype 2 and easily understand all matters.

The next is field test. The difference between the field test stage and the others is that the pretest and post-test are prepared. The pre-test and post-test given to respondents (40 peoples) in the handouts form. Based on pre-test results, the value obtained by respondents is 25 (not pass). After using prototype 2 , the value is obtained by $80 \%$ of respondents is up to 56 (enough). Thus, interactive multimedia using the Lectora inspire software is effective to be uses. 


\section{CONCLUSIONS}

Development of interactive multimedia using the Lectora inspire software for vehicle body construction in Mechanical Engineering Education study program, Universitas Sriwijaya are valid with percentage of $87.5 \%$ for multimedia and $86.9 \%$ for matters, practice with percentage in small group test of $85.52 \%$ and field test of $86.61 \%$, and effective because based on post-test results $80 \%$ of respondents was passed.

\section{ACKNOWLEDGEMENT}

This work was supported by the Institute of Research and Community Service (LPPM) Universitas Sriwijaya with grant No: 591/UN9.3.1/LT/2016.

\section{REFERENCES}

[1] A. Suharsimi and C. S. A. Jabar, Evaluasi Program Pendidikan. 2009.

[2] S. Sukiman, Pengembangan Media Pembelajaran (Yogyakarta: Pedagogia). 2012.

[3] A. Muhson, "Pengembangan Media Pembelajaran Berbasis Teknologi Informasi," Jurnal Pendidikan Akuntansi Indonesia, vol. 8, no. 2, 2010.

[4] Daryanto, Media pembelajaran. 2010.

[5] W. Saputra and B. E. Purnama, "Pengembangan Multimedia Pembelajaran Interaktif Untuk Mata Kuliah Organisasi Komputer," Speed-Sentra Penelitian Engineering dan Edukasi, vol. 4, no. 2, 2015.

[6] N. D. Shalikhah, "Media Pembelajaran Interaktif Lectora Inspire Sebagai Inovasi Pembelajaran," Warta LPM, vol. 20, no. 1, pp. 9-16, 2017.

[7] Sugiyono, Metode penelitian pendidikan:(pendekatan kuantitatif, kualitatif dan $R \& D$ ). Alfabeta, 2008.

[8] B. Warsita, Teknologi pembelajaran landasan dan aplikasinya, vol. 135. 2008. 